\title{
The intrinsic value of agency: the case of Indonesia
}

Article

Accepted Version

Fernandez, A., Della Giusta, M. and Kambhampati, U. (2015)

The intrinsic value of agency: the case of Indonesia. World Development, 70 (C). pp. 92-107. ISSN 0305-750X doi: https://doi.org/10.1016/j.worlddev.2014.12.020 Available at https://centaur.reading.ac.uk/41428/

It is advisable to refer to the publisher's version if you intend to cite from the work. See Guidance on citing.

To link to this article DOI: http://dx.doi.org/10.1016/j.worlddev.2014.12.020

Publisher: Elsevier

All outputs in CentAUR are protected by Intellectual Property Rights law, including copyright law. Copyright and IPR is retained by the creators or other copyright holders. Terms and conditions for use of this material are defined in the End User Agreement.

\section{www.reading.ac.uk/centaur}

\section{CentAUR}

Central Archive at the University of Reading

Reading's research outputs online 
Title:

The intrinsic value of agency: the case of Indonesia

\section{Abstract}

This paper analyses the relationship between agency and Indonesian women's well-being. The existing debate on empowerment mostly focuses on agency's instrumental value, how agency benefits development and household/women's welfare. We depart from this debate by considering the intrinsic value of agency for women using the Indonesia Family Life Survey. We measure agency based on the decisions women make within their households. We find the effects of agency are not unambiguously positive. Agency has intrinsic value, seen in its strong relationship to well-being in certain spheres, which is moderated by the 'burden of responsibility' that seems to be felt by decision-makers.

\section{Keywords:}

Gender, subjective well-being, agency, household decision-making, Indonesia 
This paper looks at the effect of women's agency on their subjective well-being in Indonesia. Research, to date, has tended to concentrate on the impact that agency has on the welfare of households and families. Studies analysing this instrumental impact of agency show beneficial impacts on household welfare (see for instance Abadian, 1996; Adato, Brière, Mindek, \& Quisumbing, 2003; Agarwal, 1997; Basu, 2006; Blumberg, 1988; de Brauw, Gilligan, Hoddinott, \& Roy, 2014; Hoddinott \& Haddad, 1991, 1995; Kabeer, 1994, 1997, 1999; Quisumbing \& Maluccio, 2003), although there is evidence that this is not always the case (see Duflo, 2012 for a summary). In this paper, however, we are more concerned with the intrinsic value of agency - the relationship that such agency has with the woman's own subjective well-being. Focusing wholly on the instrumental role of agency risks conflating women and their households: benefits to families like improvements in children's welfare can come at the expense of women themselves (Dasgupta, 2001).

A significant point in this context is how such agency can be measured. If agency is a person's capacity for action and their ability to identify and act on a goal (Iversen, 2003; Kabeer, 1999; A. Sen, 1985b, 2001), then the most direct way to measure women's agency is to consider who makes decisions within a household and how these decisions are made. This is the approach we use in this paper to analyse the relationship between agency and the subjective well-being of women in Indonesia. We study this using data from the Indonesia Family Life Survey (IFLS) which provides individual and household level information for 44,103 individuals in 2007.

Our paper makes a number of contributions to the literature. Firstly, though the impact of agency on household welfare has been widely researched, its impact on the subjective well-being of an individual is relatively unexplored within the empirical development literature. This is a significant omission for a number of reasons. There is a large theoretical literature on the relationship between agency and well-being which falls within the capability framework that would argue subjective wellbeing is meaningless in the absence of agency. Within the empirical literature, on the other hand, 
most analysis has concentrated on the impact that agency has on household welfare. To the extent that agency is important to a person's sense of self-worth it might well be considered to influence their well-being too.

Secondly, we measure agency directly by looking at who within the household makes specific decisions with relation to children or household expenditure. Most studies to date have tended to use proxies in the form of relative education between the spouses, relative age or relative income, which measure the woman's agency, but indirectly. Alternatively, women's autonomy has been studied more directly using measures such as the ability of women to move freely, to work or to not suffer domestic violence. Nonetheless, these are still indirect measures as they assume that freedom of mobility or of work will also be reflected in women's ability to allocate household resources, for example through household decision-making. This is an assumption that remains untested. In this paper, we use direct information not only on who makes decisions within the household but also the domains within which each partner has greater dominance.

Finally, we analyse this issue in the context of Indonesia which is a good case for several reasons. The agency enjoyed by women in Indonesia is relatively high compared to most developing countries (Bulbeck, 1997; Koning, 2000; Saptari, 2000). Despite this, it varies across groups with a range of socio-cultural arrangements - from the matrilineal Minangkabau to the bilateral Javanese to the patrilineal Batak. For instance, the Batak and Minangkabau are less likely to make child-related decisions jointly than the Javanese. Similarly, the Minangkabau are less likely to make all cash and gift-giving decisions jointly than the Batak and the Javanese. These different arrangements provide a variability in the agency levels which makes the analysis revealing. ${ }^{1}$

The rest of this paper is structured as follows. In the next section we briefly describe the context of this study. Then we consider the literature we draw on for our research, namely both well-being and 
agency. Next we describe our data and methodology before moving onto our results and discussion in Sections 4 and 5.

\section{Context}

Indonesia is culturally diverse and is made up of hundreds of ethnic groups (Sakai, 2010; Statistics Indonesia \& Macro International, 2008) with gender research revealing much heterogeneity in the gender roles and norms among the different ethnic groups (Blackburn, 2004). It is also a country in which women are frequently said to have relatively more status and agency than South or East Asian women (Bulbeck, 1997; Koning, Nolten, Rodenburg, \& Saptari, 2000; Saptari, 2000). This, together with variation in agency levels across ethnic groups make an analysis of the agency of women and its impact on their well-being revealing in Indonesia. Nonetheless, Indonesian women's agency still occurs within the context of gendered social structures and institutions and is further delineated by the state which attempts to strictly segment male and female roles in society through the Marriage Law.

The 1974 Marriage Law in Indonesia legally institutionalises the idea of separate spheres in household bargaining (Lundberg \& Pollak, 1993). The Marriage Law defines men as "heads of the family" and women as "mothers of the household" (O'Shaughnessy, 2009, p.1) and is often seen as constructing women as their husbands' appendages (Jones, 2002; O'Shaughnessy, 2009). Supporting this is the state-driven gender ideology of 'State Ibuism' (Suryakusuma, 1996) which frames motherhood as central to women's identity (Dawson, 2007; Tiwon, 1996). The word 'housewife' became associated with middle class status during the New Order era (Blackwood, 2007). Such institutionally driven division of roles has been most effective among civil servants and government officials whose performance evaluations are based partly on their wives' participation in state sanctioned women's organisations (Oey-Gardiner, 2002; Suryakusuma, 1996). Government employees are also subject to additional laws regulating marriage and divorce (Suryakusuma, 1996). ${ }^{2}$ 
In addition to the role of the state, gender norms are also defined by custom and ethnicity based legal systems (also called 'adat' law) which govern a range of rights, obligations and expectations on issues such as marriage, inheritance and dispute resolution. These 'adat' laws continue to be very important and there is often a tension between these laws and the religious and state legal systems (Buttenheim \& Nobles, 2009). State ideology and 'adat' law together set a context within which most households function. While state ideology is less effective in defining gender roles in rural communities, there is still evidence of the erosion of women's multiple roles, especially their roles as elders and 'adat' leaders (Suryakusuma, 1996). Households therefore are increasingly a locus of the conflict between official ideologies of gender relations and the multiplicity of indigenous gender identities (Blackwood, 1995; Jones, 2002; Krier, 1995; Reenen, 2000; K. Sen, 1998). The extent of this conflict varies between rural and urban, elite and non-elite households with urban, elite households more affected by state ideology and rural, non-elite households affected by 'adat' law. This conflict is highlighted in the case of the Minangkabau, a matrilineal group within which women control economic production. Despite their role in managing rice fields and as farmers, the women describe themselves as housewives which Blackwood (1995) argues is not a sign of conformity. Instead, it is a redefinition of the notion of housewife to include productive activities whilst maintaining a façade of adherence to state ideology (Blackwood, 2007). 


\section{Literature Review}

Although autonomy and agency are frequently used interchangeably, there is considerable debate about both their meanings and their differences (Abrams, 1998; England, 1993; Kabeer, 1998; Rammohan \& Johar, 2009). Overall, autonomy is typically focused on self-reliance and sufficiency (Friedman, 2000) while agency allows for cooperation as well as self-sufficiency. Our main focus is women's ability to make strategic life choices which Kabeer (1999) argues is a characteristic of both autonomy and agency. We choose to focus on women's agency in this paper because we see households as sites of interdependence, cooperation and conflict (A. Sen, 1989, 1990) within which both self-reliance and cooperation are important.

Subjective well-being can be defined as "feeling good - enjoying life and wanting the feeling to be maintained" (Layard, 2006, p.12). While self-reported subjective well-being is generally seen as a good measure since people can consistently evaluate their own well-being (Frey \& Stutzer, 2002), it can be unreliable in circumstances where agency is missing (A. Sen, 2001). As Sen notes "a purely subjective form of utility [can be] moulded by social conditioning and a resigned acceptance of misfortune" (A. Sen, 1990, p.133) so that people report being happy even in quite extreme conditions of poverty or lack of agency. Sen proposes the idea of positional objectivity - which requires a person to move beyond the narrow perspective granted to them by their position within their society - as a means of understanding such inequality (A. Sen, 2009). This would enable a person to question accepted norms and practices within society. In this context, Sen argues in favour of objective measures of welfare and against an evaluation of welfare based only on an individual's subjective assessments (Peter, 2003; A. Sen, 1990). While we agree that such adaptation to adverse circumstances makes subjective well-being problematic, we would argue that a lack of happiness in such circumstances is equally problematic. While policy makers and society at large clearly need to engage with the lack of agency, from the individual woman's perspective, the lack of subjective well- 
being is an important problem. Therefore, for an individual, both objective and subjective evaluations matter as they reflect a holistic continuum from resources to the capability to use these resources and then onto well-being (Della Giusta, Jewell, \& Kambhampati, 2011). Our research here focuses on one element of this continuum - subjective well-being. This focus is not an endorsement for a subjective approach in preference of an objective one - both are needed for a balanced appraisal of a person's life.

Research shows gender differences in both self-reported well-being as well as the factors that influence well-being. Much of the existing literature on subjective well-being is focused on personal characteristics, microeconomic and macroeconomic factors (such as income, hours worked, inflation and unemployment) and social relationships (Argyle, 2003; Clark, Knabe, \& Ratzel, 2010; Diener, Ng, Harter, \& Arora, 2010; Diener \& Suh, 2000; Dolan, Peasgood, \& White, 2008; Easterlin, 2001; Frey \& Stutzer, 2002; Kahneman, Diener, \& Schwarz, 2003; Kenny \& Kenny, 2006; Layard, 2006; Stutzer \& Frey, 2010; Tella, MacCulloch, \& Oswald, 2003). Studies in Western market economies find that while hours of paid employment increase both men's and women's subjective well-being (Della Giusta et al., 2011), employment is more central to men's rather than women's well-being (Argyle, 2003), as is job satisfaction (Della Giusta et al., 2011). There is little overall difference in the impact of being married on men's and women's subjective well-being but a bad marriage has a greater negative impact on women than on men (Myers, 2003) while caring for dependents negatively affects women's but not men's subjective well-being (Della Giusta et al., 2011).

Thapan (2003), in a study of subjective well-being in India found that education, number and sex of children, social relationships, deprivation and social norms for women are all significant determinants in India. Others, studying various developing countries, have found that well-being is associated with income (Argyle, 2003), relative standing (Bookwalter \& Dalenberg, 2010), income inequality (Jiang, Lu, \& Sato, 2012), rural-urban migration (Knight \& Gunatilaka, 2010), caste 
(Fontaine \& Yamada, 2014), political liberalisation (Richter, 2009) and urban vs. rural settings (Easterlin, Angelescu, \& Zweig, 2011).

Using almost the same household decisions as we use here, albeit from a different wave of the IFLS, Rammohan and Johar (2009) studied the determinants of married women's autonomy. In contrast to our research, they used women's household decision-making as the dependent variable, sorting women into three groups by type of autonomy. Similarly, household decision-making was also the dependent variable in research on the determinants of women's autonomy using the Ethiopian Demographic Health Survey (DHS) which studied decision-making control over own health, daily household needs, large purchases for the household and visiting friends and family (Mabsout \& van Staveren, 2009). Garikipati (2008), in a study using women's say in household decision-making as an empowerment indicator, awarded points for women's contribution both to making and initiating different types of decisions such as children's education, crop, stock or land decisions, major financial decisions and sale negotiations.

Research in psychology provides support for the linking of agency (control) with subjective wellbeing. A perceived lack of agency has been shown to negatively impact a person's self-esteem as well as their ability to perform a task and may even prevent a person from making an attempt (Fast, Gruenfeld, Sivanathan, \& Galinsky, 2009; Grob, 2000; Skinner, 1995). Some studies also suggest a link between gender inequality and lower well-being for women, attributable to women's relative powerlessness compared to men (Cassidy \& Davies, 2003; Rosenfield, 1989). While men and women experience similar levels of mental health problems, the types of problems differ by gender with women being more likely to suffer from internalizing disorders and greater feelings of hopelessness and helplessness than men (Rosenfield, 1999; Rosenfield \& Mouzon, 2013). However, agency can act as a moderating factor because of the perceived control it conveys as seen in a study of depression and exposure to stress among disadvantaged women (Grote, Bledsoe, Larkin, Lemay, \& Brown, 
2007). In the next section, we will describe the data and methodology that we will use in our analysis of women's agency and well-being in Indonesia.

\section{Data and Methodology}

As mentioned earlier, we analyse our research question using data from Indonesia.

\section{Data}

The IFLS is a continuing longitudinal socioeconomic and health survey with the next wave planned for 2014-2015. The households which were included in the IFLS at inception in 1993 were representative of $83 \%$ of the Indonesian population and drawn from 13 of the 26 provinces, both rural and urban. Each wave was administered to the original households from 1993 and to split-offs from those households, achieving a high re-contact rate of $90.6 \%$ for target households (Strauss, Witoelar, Sikoki, \& Wattie, 2009). The IFLS provides data on a broad range of topics including both economic and non-economic well-being indicators like consumption, income, assets and household decision-making (Frankenberg et al., 1995), making it a suitable choice for our research. There are four waves of the IFLS, starting in 1993 and ending in 2007. In this paper, we use the most recent wave of the IFLS (2007) as this was the only year in which the subjective well-being question was asked. In this wave, 13,535 households and 44,103 individuals were interviewed from both rural and urban enumeration areas. Interviews were conducted with several people within the household, not

just the household head. ${ }^{3}$ For the decision-making module, both the household head and his or her spouse were interviewed (Strauss et al., 2009). We use data from both husbands and wives in our estimations which include rural and urban households. ${ }^{4}$ 


\section{Measuring subjective well-being}

Our dependent variable is subjective well-being which was collected in IFLS4 from the question in Book 3A:

"Taken all things together how would you say things are these days - would you say you were very happy, pretty happy, or not too happy?"

Answers in the IFLS4 are ascribed to a four-step Likert scale coded so that one represents 'very unhappy' and four represents 'very happy'. The relationship between agency and subjective wellbeing is analysed using an ordered probit model which is commonly used for this type of analysis. This model was chosen as the data on subjective well-being takes the form of a four-step ordinal scale variable with a clear natural ordering.

(Insert Table 1 here)

Approximately $85 \%$ of both men and women reported that they were fairly happy. The mean subjective well-being score was 2.96 (std. dev. 0.3977) for men and 2.98 (std. dev. 0.3956) for women.

We estimate the following model separately for men and women in our sample ${ }^{5}$

$$
s w b_{i}=\beta_{1} x_{1 i}+\beta_{2} x_{2 i}+\beta_{3} x_{3 i}+\beta_{4} x_{4 i}+\beta_{5} x_{5 i}+\mu_{i}
$$

Where:

$s w b_{i}$ denotes the subjective well-being for an individual, $(i=1,2, \ldots . . N) ; x_{1}$ denotes the vector of respondent's demographic characteristics (age, religion, ethnicity, education); $x_{2}$ denotes the vector of financial resources (income, use of loans, asset ownership); $x_{3}$ denotes the vector of social capital proxies (cooperation, security); $x_{4}$ denotes the vector of agency proxies; $x_{5}$ denotes the vector of 


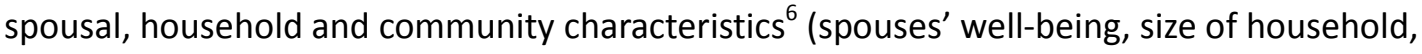
household's use of electricity, community access to healthcare and electricity); and $\mu_{\mathrm{i}}$ denotes the error term. The model allows us to control for a range of factors influencing well-being and therefore estimate specifically the impact of agency $\left(x_{4}\right)$ on well-being.

(Insert Table 2 here)

(Insert Table 3 here)

Based on the general model above, we estimate four models in this paper, each of which includes a different set of agency proxies. Model 1 is a reduced form model which includes indirect proxies (like relative age and relative education of the spouses) for agency. These are the measures which have been most commonly used within the literature and therefore Model 1 allows us to link into the existing literature. Model 2 uses direct proxies for agency in the form of household decision-making variables. In Models 3 and 4, we allow for the possibility that the error terms for husbands and wives are correlated by estimating Seemingly Unrelated Regression (SUREG) models. Although this required us to constrain the sample to only those households where data was available for both spouses (leaving us with a sample 7,759 individuals), it allows us to include spouse well-being into the respondent's well-being model (Model 3). In Model 4, we create a single measure of decisionmaking by linearly combining all the different spheres of household decision-making.

As we are primarily interested in the relationship between agency and subjective well-being, we will concentrate on these variables in the rest of this paper. The descriptive statistics for all the variables are provided in Tables 2 and 3.

\section{Measuring Agency}

Until very recently, agency was typically modelled as intra-household inequalities in age, income or education (Anderson \& Eswaran, 2009; Felkey, 2013; Kritz \& Makinwa-Adebusoye, 1999; Mabsout \& 
van Staveren, 2009; Quisumbing, 2003). More recently, the collection of data on decision-making within households (as done both by the DHS and the IFLS) has facilitated the use of direct measures of agency (Anderson \& Eswaran, 2009; Felkey, 2013; Garikipati, 2008; Jejeebhoy, 2002; Mabsout \& van Staveren, 2009; Quisumbing, 2003; Rammohan \& Johar, 2009). This measures the influence and authority wielded by each spouse as revealed in the decisions they make (Anderson \& Eswaran, 2009). In the following sub-sections, we discuss all the agency variables included in our models.

(Insert Table 4 here)

\section{Relative income}

Relative income between spouses has often been used as a proxy for women's agency (Felkey, 2013; Kambhampati, 2009). It is seen to be a variable that reflects the extent of bargaining power each spouse would wield within the household, given their contribution to the household's economic resources. As a measure of agency or even bargaining power, it faces two main problems. Firstly, it is only an indirect proxy for women's agency and secondly, it is likely to be endogenous to previous household decisions. This variable is also unable to capture the intricacies of households as sites of competing interests, cooperation, conflict and differing areas of authority. In addition, it cannot capture how slow moving social norms can offset and limit the agency that women gain from income (Mabsout \& van Staveren, 2009). In this paper, we include it as a variable in our preliminary estimates to allow comparison across studies.

Relative income is formulated as the ratio of either wives' income to joint spousal income (for women) or husbands' income to joint spousal income (for men). Men contributed $62 \%$ of joint spousal income in our sample. 
Unlike relative income, relative education is likely to be exogenous, having been undertaken prior to marriage in most cases. Relative education between spouses has often been used as a proxy for women's agency (Anderson \& Eswaran, 2009; Mabsout \& van Staveren, 2009; Quisumbing, 2003) because educated women are likely to be more knowledgeable about their outside options, more articulate and therefore more persuasive in the context of intra-household bargaining. Women's education should also enable access to employment opportunities, increase women's awareness of their options, increase human capital and give women the confidence to use their agency. In this paper, relative education is a dummy variable which is equal to one where wives' education level is greater than their husbands' (for women) and vice versa (for men). We use the highest level of schooling completed by both spouses. Table 4 indicates that $22 \%$ of men had more education than their spouses compared to $12 \%$ of women. In the vast majority of cases, therefore, both spouses have equal levels of education. This is confirmed by figures for primary schooling in Indonesia of $93 \%$ for boys and $98 \%$ for girls (Statistics Indonesia \& Macro International, 2008). ${ }^{7}$

\section{Relative age}

Relative age is formulated as the ratio of wives' age to husbands' age for women and vice versa for men (Anderson \& Eswaran, 2009; Kritz \& Makinwa-Adebusoye, 1999; Mabsout \& van Staveren, 2009). It is expected that if women are much younger than their husbands they will have less autonomy and independence, making relative age a good proxy for capturing women's agency.

There is a small gap between average relative age of husbands and wives in our sample although this average is higher when men are older than their spouses ( 1.14 compared to 0.89 ). 
As seen in the literature review, a number of studies (Garikipati, 2008; Mabsout \& van Staveren, 2009; Rammohan \& Johar, 2009) model agency as decision-making. Our measure of agency is in the spirit of these studies, concentrating on decision making in six domains - child-related decisions, large household expenditures, small household expenditure, cash and gift-giving, savings and leisure. In each of these domains (except leisure), decisions can be made by the respondent only, the respondent's spouse only, jointly by the respondent and spouse or by others. Decisions relating to leisure are made only by the respondent. Our single measure of decision-making calculates the proportion of decisions across all domains that are made each by the respondent alone, by his or her spouse, by the respondent and spouse jointly or by others. Details of the construction of our decision-making variables are in the Appendix.

(Insert Table 5 here)

Table 5 above provides summary statistics for our decision making variables. For men and women, we see that in all five domains where joint decision-making is possible, the decisions are predominantly made jointly except for small household expenditures where a majority of the decisions are made by women. For women, joint decision-making dominates decisions made by all other agents in all five domains. Not all types of decisions made within a household are of equal importance (Kabeer, 1999) so the separation into these decision groups captures different types and levels of agency. As such, we consider each of these domains more carefully in what follows.

\section{The financial decisions}

Decisions relating to small household expenditure, savings, large household expenditure and gift giving are all financial decisions. Table 5 indicates that the vast majority (approximately 80\%) of both large household expenditure decisions and gift giving decisions are made jointly by the spouses. 
While savings decisions are also made jointly, this is a much lower proportion of decisions at approximately $33 \%$. Finally, we see that the vast majority (approximately 64\%) of small expenditure decisions are made by the woman alone.

While small household expenditure decisions, by definition, involve smaller amounts of money they are fungible and therefore give women flexibility which might help increase their subjective wellbeing. In our sample, women typically make these decisions on their own with over $80 \%$ of men taking no part in these types of decisions.

In Indonesia, participation in community or village ceremonies is the norm, often requiring reciprocal gift giving. Similarly, transfers of money within the extended family to those in need are a common occurrence (Park, 2003). We expect control over cash and gift-giving decisions to increase subjective well-being as it facilitates social relationships and also brings the expectation of future reciprocity.

These financial decision-making variables can be used to test whether a woman's control over resources within the household increases her subjective well-being. Control over these resources increases women's capability set and, therefore, their ability to cope with their life conditions regardless of whether women choose to use this agency.

\section{Decisions relating to children}

A major sphere of decision-making amongst married couples relates to children. This might include economic choices (how much to spend on their food, education, health etc.) as well as noneconomic choices (which school to send them to, the level of freedom they enjoy and so forth). The ability to make decisions in this sphere reflects a level of agency for women, which could help increase their well-being.

Table 5 indicates that despite state attempts to delineate children and the home as the woman's domain through the Marriage Law, $70 \%$ of child-related decisions are jointly made. It also indicates 
that $14 \%$ of child-related decisions are made by wives (for men) but only $3 \%$ are made by husbands (for women). Exercising agency in relation to child-related decisions should increase women's subjective well-being. Even though these decisions capture women's agency constrained by their domestic roles, there are benefits to women's subjective well-being from 'doing gender' (Bittman et al., 2003; Greenstein, 1995, 2000; Gupta, 2006; Ono \& Raymo, 2006; Tichenor, 1999). Also, children in Indonesia typically support their parents in old-age. Women are less likely to be employed in pensionable, formal sector jobs and have less access to financial resources than men (Koning et al., 2000; Philip Kreager \& Schroder-Butterfill, 2009; Schroder-Butterfill \& Kreager, 2007), so control over this decision-type could function as a form of future social security.

\section{Other decisions - own leisure time}

The ability to control one's own time use is likely to positively impact subjective well-being especially when it enables individuals to make decisions about their leisure time. Such control may enable women to regulate the extent to which they are affected by a double or triple shift (Moser, 1989). Control over leisure time encompasses considerations such as time spent with family which should also positively affect subjective well-being. $43 \%$ of men and $33 \%$ of women make decisions regarding their use of their leisure time.

\section{Issues arising}

Before we move on to our results in the next section, it is worth considering methodological issues that arise in estimations of this kind. The most important of these is the issue of endogeneity which affects most analyses of well-being and might arise either from reverse causality or from variables omitted from our analysis. If a variable that influences subjective well-being (like personality) is not included in the model, then it affects the error term and because its effect persists over time, it could bias our estimates. As previously noted, ours is a cross-section dataset as only the IFLS4 included the subjective well-being question. Fixed effects methods could not be used, leaving time dependence in 
income or subjective well-being unaddressed. Our results are therefore probably better viewed as correlations between subjective well-being and specific proxies for women's agency. In addition, there is also the possibility in estimations of this kind that employment, income, marital status and other variables may not really be exogenous, being dependent on people's sense of satisfaction to begin with (Ferrer-i-Carbonell \& Frijters, 2004). To correct for potential endogeneity arising from the inclusion of income, we use a lagged income variable (i.e. income not from the time of the interview but from the preceding year) as an instrument for current income in our model. To the extent that there is path-dependence in income earned lagging in this way mitigates, but does not completely remove, endogeneity. Finally, since the IFLS data on household decision-making ${ }^{8}$ was only collected from married couples, we do not include marital status in our model. Our estimates may, therefore, also be affected by sample selection that is inherent in the dataset and any study of intra-household bargaining.

\section{Estimation results}

Table 6 presents our estimation results. As already discussed above, we estimate four versions of our model. The first includes spousal inequality proxies for age, income and education (Model 1), while the second includes direct decision making variables. Models 3 and 4 are estimated on a dataset limited to matched couples into which spousal well-being could be included. They are estimated using SUREG methodology. Model 4 has a single, scalar measure of decision-making for the proportion of all the household decisions made by the respondent, his/ her spouse, jointly or by others. Table 6 presents the results only for our direct and indirect measures of agency. The controls included in the models are household income, asset ownership, borrowing, age, education levels, social capital, household size, access to healthcare and electricity, ethnicity and religion. The results of these controls are not presented in the tables to keep them manageable. In the rest of this section, we will concentrate on the decisions which have a significant relationship with subjective well-being, focusing on decisions made by the respondent, his or her spouse and joint decisions. We 
will not discuss decisions made by third parties ${ }^{9}$ as these are a very small proportion of decisionmakers. In each case, the base category is decisions made by the individual himself or herself so all coefficients are interpreted using this base.

Our results show a relationship between agency and a person's subjective well-being. In addition, this relationship differs for men and women. We find that the relationship between agency and subjective well-being can be either positive or negative, depending on the domain over which agency is exercised.

[Insert Table 6 here]

\section{The indirect proxies for agency}

Table 6 (Model 1 ) indicates that relative income is not significantly related to well-being for either men or women. We can speculate that relative income might be a less effective measure of agency in Indonesia because most Indonesian women are either economically active (Elmhirst, 2000) or manage household finances (Brenner, 1995). Relative age, on the other hand, is positive and significant for women. This indicates that women's well-being is higher when they are closer in age to their husband. Finally, we find in Model 1 that relative education has a significant, negative effect on the well-being of men leading us to conclude that men in Indonesia are happier when their wives are as educated as they are. This might relate to a man's prestige being associated with his wife's level of education. Alternatively, it might result from the failure to match themselves to wives with similar education being seen as poor performance in the marriage market. ${ }^{10}$ However, it might also relate to the fact that educated women are better able to contribute to household decisions (for instance with regard to finances or children) which takes the pressure off men and leads to them feeling happier. 


\section{The direct measures of agency}

In the following discussion, we consider the results separately for men and women.

Men

Looking at the estimation results for Model 4 first (Column 7 of Table 6), we see a significant and positive relationship between men's subjective well-being and not having sole responsibility for household decision-making. Thus, men are happiest when decisions are made jointly rather than by themselves alone (the base category). They are happier (though less than in the case of joint decision-making) when their spouses or others make these decisions. These results seem to indicate that, for the vast majority of household decisions, men prefer to share or hand over responsibility. What is not clear, however, is whether this differs across the various domains of decision making. Turning to Model 2, we see that different types of decisions affect men's subjective well-being in different ways (Column 3 of Table 6). Men's subjective well-being is lower when the proportion of child-related decisions made by their spouses' increases as compared to a situation where they make these decisions themselves. This is a surprising result in light of the fact that children typically fall primarily within women's domain in the household (Folbre, 1994a, 1994b) and the state in Indonesia declares it as such. Another sphere of decision-making that men would prefer to control is cash and gift-giving: their well-being is significantly lower when their spouses control this aspect of household behaviour. Looking at marginal effects ${ }^{11}$ at the mean (Table 8 ), men are $2.7 \%$ more likely to be in the 'unhappy' category when their wives make cash-giving decisions. This includes both the giving of monies to one's own parents or other family members, one's in-laws and gift-giving for parties and weddings. For many ethnic groups in Indonesia, elderly family members receive support from both sons and daughters. But, sons typically provide monetary support while daughters provide personal care (Philip Kreager \& Schroder-Butterfill, 2009; P. Kreager \& Schröder-Butterfill, 2005; SchroderButterfill \& Kreager, 2007), which might explain the relationship between having control over this 
variable and well-being for men. It is also a very visible form of agency and so there might be status associated with it.

On the other hand, men's well-being is positively associated with their spouses making a higher proportion of savings decisions. Looking at marginal effects (compared to the mean) in Table 8, men are $2.6 \%$ more likely to fall into the 'very happy' category if their wives make all savings decision and $2.8 \%$ more likely to fall in that category when decisions are made jointly. Finally, men's subjective well-being is significantly greater when they control use of their leisure time. Despite the reduced sample size and the inclusion of spousal well-being in Model 3, the savings and own leisure coefficients remain significant.

Overall, therefore, in Indonesia we can conclude that men's subjective well-being is higher when they are not solely responsible for financial decisions (except gift giving). It is also higher when they can keep control of child-related decisions, use of their leisure time and gift giving. These results imply that cooperation can be beneficial to men's subjective well-being, but not in every situation.

\section{Women}

Our results for women's well-being, on the other hand, indicate that the proportion of all household decisions made by her spouse is not significantly associated with a woman's well-being (Column 8 , Table 6). Model 2 indicates that women's well-being is not related to the proportion of child-related, large and small household expenditure decisions made by her spouse. While the result with respect to child-related decisions is surprising, it might indicate that this is a sphere within which women are sufficiently confident such that they do not feel threatened when their spouses make more of these decisions. On the other hand, it might indicate that women's well-being is enhanced by cooperation within their relationship. However, women's subjective well-being (like their spouses') is better if they can make decisions about gifts jointly, perhaps for similar reasons to those discussed above. Looking at marginal effects at the mean, they are $2.8 \%$ more likely to be in the 'very happy' category 
when these decisions are made jointly. Indonesian women, in particular elite Javanese women, are often responsible for managing the social and community relationships on behalf of their families (Weix, 2000) and are heavily dependent on informal and formal networks (Wolf, 2000). In this context, having some control over cash and gift-giving is likely to be important to maintaining these networks which, in turn, is crucial for the individual's well-being. Similar to the results for men, the larger the proportion of savings-related decisions made by their spouses, the higher is women's wellbeing (Column 4, Table 6). Compared to the mean, women are $6.4 \%$ more likely to fall into the 'very happy' category when their husbands make all savings decisions and $1.7 \%$ more likely to be in this category when decisions are made jointly (Table 8). Thus, women's subjective well-being increases when savings decisions are not entirely their own responsibility but are made jointly or wholly by her spouse.

\section{The burden of responsibility}

Our results lead us to conclude that women (and men) in Indonesia are happier when most decisions are jointly made rather than when they are made solely by them. This could arise from the fact that agency comes with a burden of responsibility. Our results suggest that, for men at least, having less responsibility or sharing it with their wives is associated with higher subjective well-being. However, not all forms of responsibility are equally burdensome. Some financial decisions, like savings, have a long term impact on a household's living standards, carry more responsibility, result in greater blame in the event of a bad decision and are often a major source of contention (Vogler, Lyonette, \& Wiggins, 2008). Our estimation results show that not being wholly responsible for savings decisions is related to greater subjective well-being for both men and women in Indonesia.

For women, this 'burden of responsibility' effect appears to affect both cash giving and savings decisions. Collaborative approaches or even relinquishing control are more beneficial to women's subjective well-being than more individualistic approaches. This suggests that attempts to improve 
women's agency by increasing their control over finances might not necessarily improve their subjective well-being. It is too simplistic to assume that all factors which improve a woman's outside options in the context of marital breakdown will automatically increase their subjective well-being instead a more nuanced approach is needed. Social norms typically restrict key decision-making areas to men's control as heads of households (Kabeer, 1999) while research in both Indonesia and the Philippines shows both men and women verbalizing the gender stereotype that men lack the self-control to manage the household finances (Ashraf, 2009; Brenner, 1995). This suggests that having sole control over household finances requires women to balance controlling their husbands' behaviour (to avoid depleting household resources) with conforming to social norms. Arguably, avoiding having to control their husband's behaviour might be why joint decision-making has a positive impact on women's but not men's subjective well-being as it alleviates some of this conflict for women.

\section{Discussion}

Our results are surprising and seem to indicate two things. Firstly, Indonesia is different from other countries where female agency studies have been conducted in that there is significant equality to start with as indicated by our summary statistics. This might be why men and women prefer to collaborate on most household decisions. This is also seen from our results for relative education, which indicated that men preferred wives who had education levels similar to their own. Secondly, while decision-making might reflect increased agency this need not increase well-being. With increased agency comes increased responsibility which might well increase burdens, as we saw above.

There is significant evidence that agency is an important aspect of well-being, interpreted broadly. Sen's capability framework would argue that agency is essential in providing individuals with choices which increases the capability set (A. Sen, 1985a; A. Sen, 1993). The Millennium Development Goals 
(MDGs), as well as the post-2015 development agenda, are predicated on the notion that greater agency for women is better than less as it is likely to help both development and family welfare. Our results, however, seem to indicate that increased agency is not necessarily related to increased subjective well-being. It seems necessary and important to understand this result.

In this context, it is worth noting that the IFLS specifically asked about happiness rather than a more evaluative measure of well-being such as life satisfaction. While individuals may not be 'happy' with increased responsibility, the ability to make decisions and be independent is likely to increase their satisfaction with their life and therefore their longer term well-being. Thus, to the extent that wellbeing has both subjective and objective facets (including welfare, contentment and dignity (Kenny \& Kenny, 2006)), we might expect agency to have a positive impact on well-being broadly though the impact on short-term happiness might not be straightforward.

In addition, it is possible (and likely) that the case of Indonesia is different to that of most developing countries in terms of the roles of men and women. The adherence to socially prescribed roles for women does not seem to increase women's subjective well-being - perhaps because these gendered roles have become naturalized and are not open to negotiation (Agarwal, 1997; Kabeer, 1999). It is also possible to speculate that this might be due to women's duties as wives and mothers being enshrined in law in Indonesia such that the domestic domain forms the main locus of women's identity. The Marriage Law No. 1/1974 turns into an obligation what might otherwise be a choice and details women's five 'key duties' which include a responsibility to procreate and care for children (Yulindrasari \& McGregor, 2011). This process results in women being trapped in their 'natural' roles without being able to question if this is what they really want or make a choice as to their behaviour. It is interesting to speculate what the impact might be if this 'naturalized' role were to be taken away from women - would it increase or decrease their subjective well-being? If the gender socialization of women is strong enough and widely enough held, losing this role might decrease their subjective well-being. 


\section{Conclusion}

This paper began with an acceptance that agency is 'good' for both men and women. It is what defines the freedom of the individual. We also know that women's agency has been identified as being beneficial for household welfare in a range of studies across many countries. Our research does not discount the importance and relevance of agency's instrumental value. Instead, our objective in this paper was to consider if such agency is also linked with an increase or a decrease in subjective well-being. In other words, does agency have intrinsic value? Our results show that agency is intrinsically valuable as seen in its strong relationship to subjective well-being. But, this relationship is not always straightforward.

We have analysed this relationship using decision-making variables, which are direct measures of agency. Household decision-making is essentially about control of different aspects of life within the family which makes these proxies a good tool for capturing the relationship between agency and subjective well-being. We find that, of all the types of decisions in the IFLS4 dataset, the decisions which affect subjective well-being are financial decisions, child-related decisions and decisions over one's own leisure time.

The interplay of agency and the 'burden of responsibility' on subjective well-being might be a possible explanation for the sometimes unforeseen outcomes that result from development or empowerment initiatives. Women might hesitate to use or participate in initiatives which increase this 'burden of responsibility' as their subjective well-being suffers. We are not advocating ignoring agency in favour of a complete focus on subjective well-being. Instead, our research posits that agency and subjective well-being need to be considered together as both are necessary to one's holistic physical and psychic well-being. 
Appendix 1: Summary statistics and additional estimation results

Table 7 Descriptive statistics and construction of the decision-making variables

\begin{tabular}{|c|c|c|}
\hline Variable & How the variable was created & $\begin{array}{c}\text { Cronbach's alpha } \\
\text { score* }\end{array}$ \\
\hline $\begin{array}{l}\text { Proportion of child- } \\
\text { related decisions made } \\
\text { by spouse }\end{array}$ & $\begin{array}{l}\text { One dummy variable was created for each child } \\
\text { related decision (children's health, children's } \\
\text { education and children's clothes) made solely by } \\
\text { spouses. } \\
\text { These three child-related decisions were added } \\
\text { together and normalized to proportions of } 1 \text { to } \\
\text { make a single child-related decision making variable } \\
\text { to show the proportion of decisions made by } \\
\text { spouses. }\end{array}$ & 0.73 \\
\hline $\begin{array}{l}\text { Proportion of cash- } \\
\text { giving decisions made } \\
\text { by spouse }\end{array}$ & $\begin{array}{l}\text { Method as above for giving money to the } \\
\text { respondent's family, giving money to spouse's family } \\
\text { and gifts for parties/weddings. }\end{array}$ & 0.72 \\
\hline $\begin{array}{l}\text { Proportion of savings } \\
\text { decisions made by } \\
\text { spouse }\end{array}$ & $\begin{array}{l}\text { Method as above for monthly ROSCA and monthly } \\
\text { savings. }\end{array}$ & 0.51 \\
\hline $\begin{array}{l}\text { Proportion of small } \\
\text { household expenditure } \\
\text { decisions made by } \\
\text { spouse }\end{array}$ & $\begin{array}{l}\text { Method as above for expenditure on food eaten at } \\
\text { home and routine household purchases. }\end{array}$ & 0.86 \\
\hline Proportion of large & One dummy variable was created for the decision & \\
\hline
\end{tabular}




\begin{tabular}{|c|c|c|}
\hline Variable & How the variable was created & $\begin{array}{c}\text { Cronbach's alpha } \\
\text { score* }^{*}\end{array}$ \\
\hline $\begin{array}{l}\text { household expenditure } \\
\text { decisions made by } \\
\text { spouse }\end{array}$ & $\begin{array}{l}\text { on large household expenditure made solely by } \\
\text { spouses. There was only one decision of this type. }\end{array}$ & \\
\hline $\begin{array}{l}\text { Proportion of child- } \\
\text { related decisions made } \\
\text { jointly }\end{array}$ & $\begin{array}{l}\text { Method as above for children's health, children's } \\
\text { education and children's clothes. }\end{array}$ & 0.83 \\
\hline $\begin{array}{l}\text { Proportion of cash- } \\
\text { giving decisions made } \\
\text { jointly }\end{array}$ & $\begin{array}{l}\text { Method as above for giving money to the } \\
\text { respondent's family, giving money to spouse's family } \\
\text { and gifts for parties/weddings. }\end{array}$ & 0.80 \\
\hline $\begin{array}{l}\text { Proportion of savings } \\
\text { decisions made jointly }\end{array}$ & $\begin{array}{l}\text { Method as above for monthly ROSCA and monthly } \\
\text { savings. }\end{array}$ & 0.61 \\
\hline $\begin{array}{l}\text { Proportion of small } \\
\text { household expenditure } \\
\text { decisions made jointly }\end{array}$ & $\begin{array}{l}\text { Method as above for expenditure on food eaten at } \\
\text { home and routine household purchases. }\end{array}$ & 0.76 \\
\hline $\begin{array}{l}\text { Proportion of large } \\
\text { household expenditure } \\
\text { decisions made jointly }\end{array}$ & $\begin{array}{l}\text { One dummy variable was created for the decision } \\
\text { on large household expenditure made by } \\
\text { respondents and spouses. There was only one } \\
\text { decision of this type. }\end{array}$ & \\
\hline
\end{tabular}

*Used to check the suitability of these groupings 
Table 8 Extract of significant marginal effects from subjective well-being Model 2

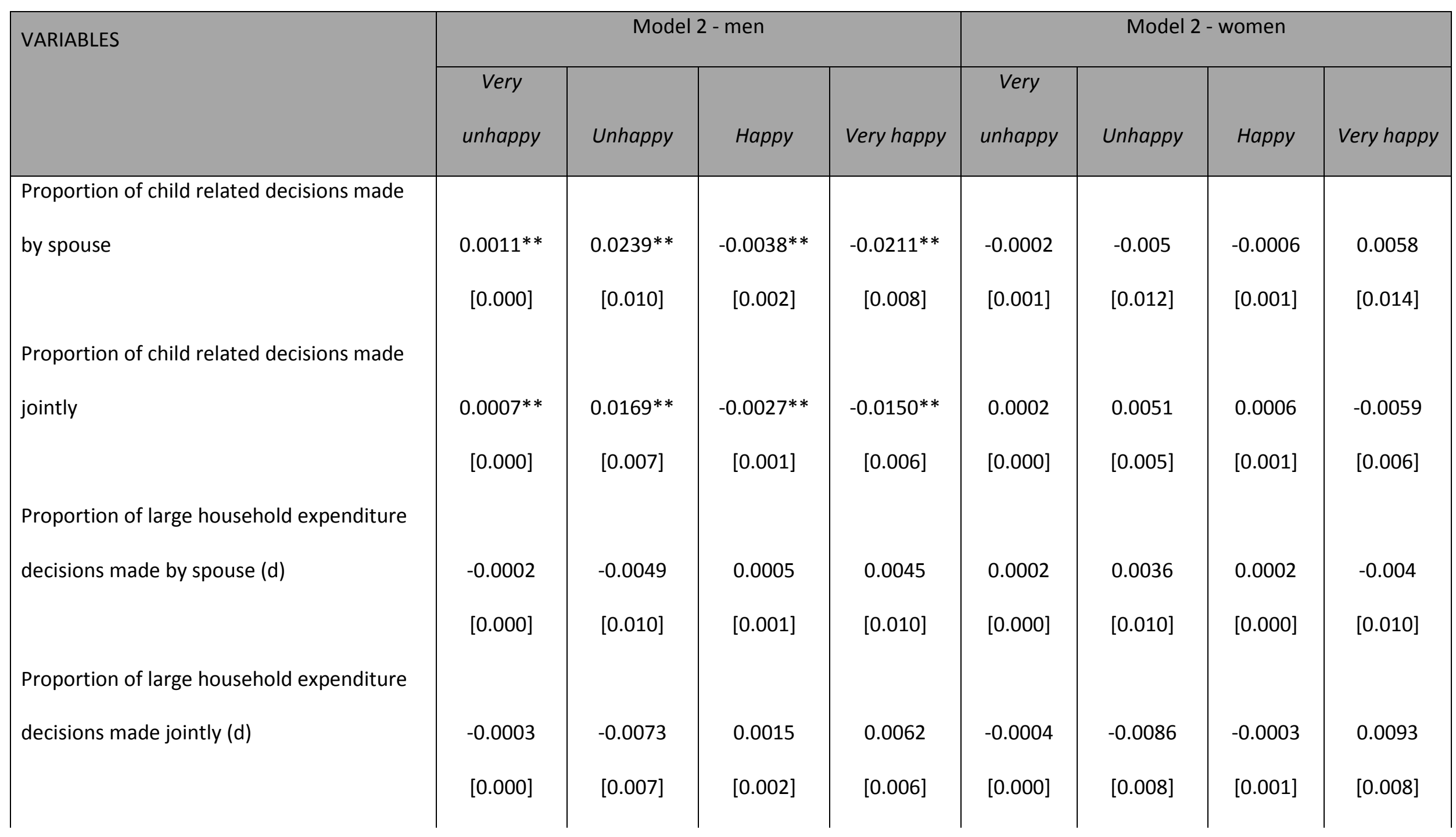




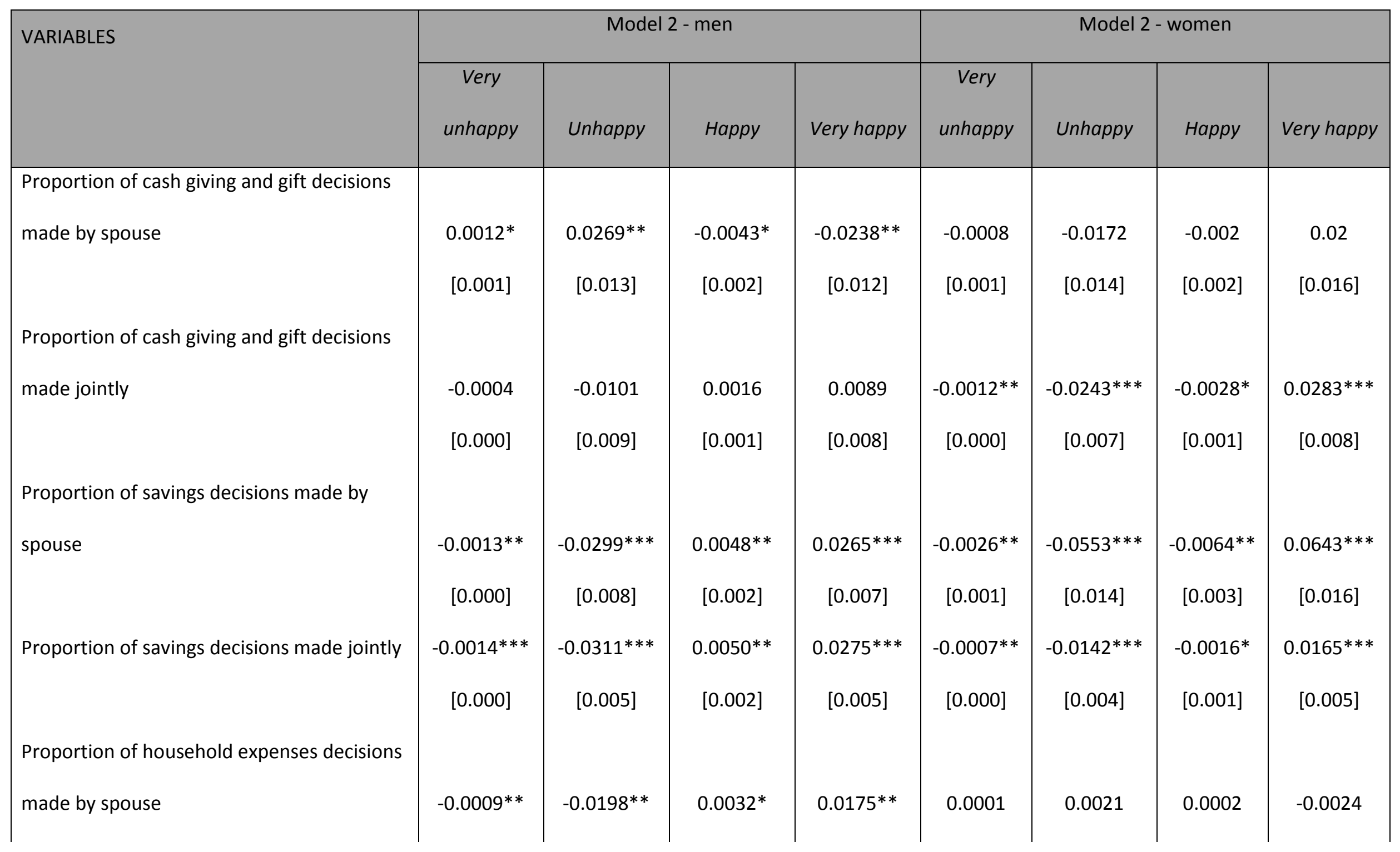




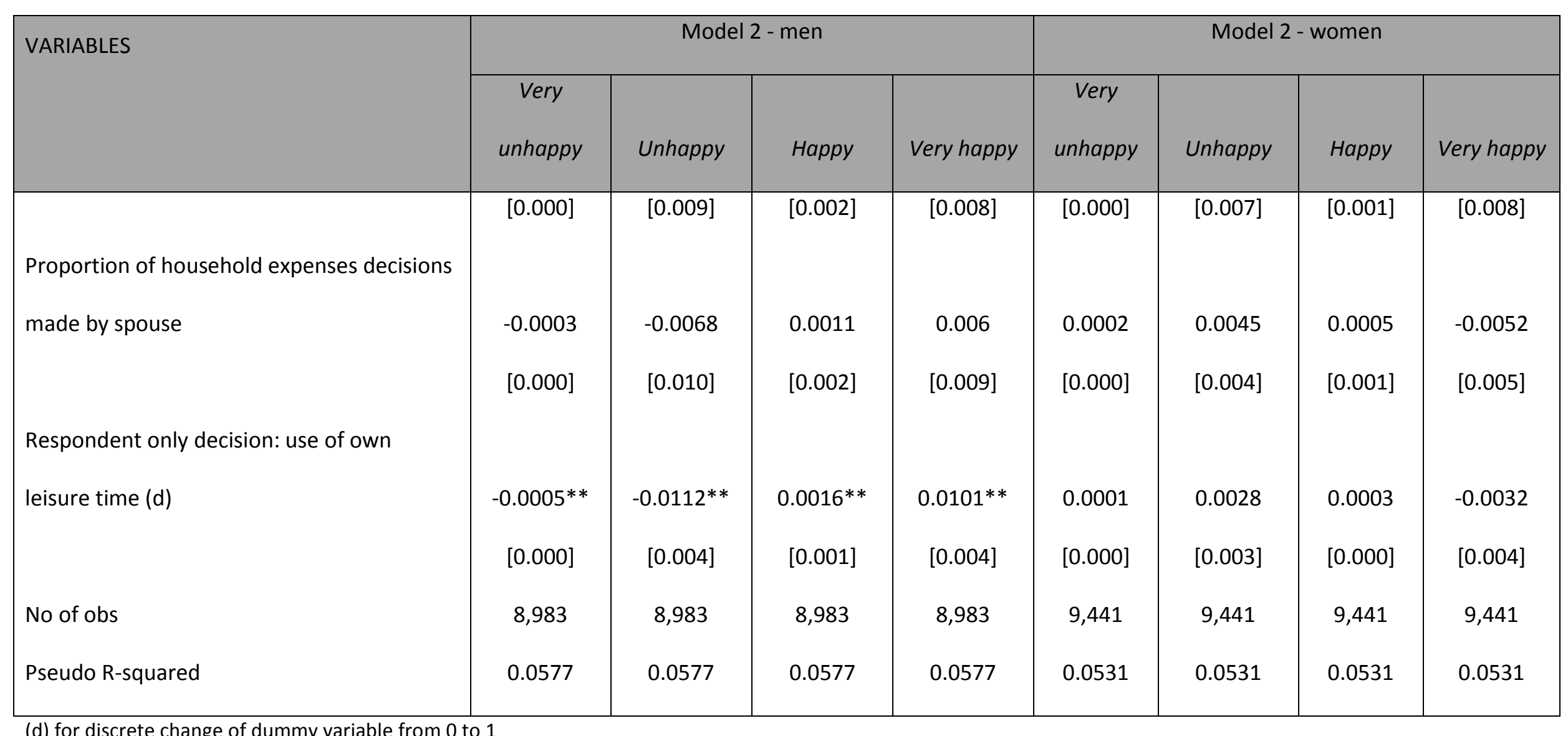

(d) for discrete change of dummy variable from 0 to 1

Standard errors in brackets, $* p<0.10, * * p<0.05, * * * p<0.001$

Dependent variable is subjective well-being where 1=very unhappy; $2=$ =unhappy; 3=happy; and 4=very happy 


\begin{tabular}{|l|c|c|c|c|c|c|c|}
\hline \multirow{2}{*}{ VARIABLES } & \multicolumn{3}{|c|}{ Model 2 - men } & \multicolumn{2}{c|}{ Model 2 - women } \\
\cline { 2 - 7 } & Very & & & & Very & & \\
unhappy & Unhappy & Happy & Very happy & unhappy & Unhappy & Happy & Very happy \\
\hline
\end{tabular}

Marginal effects at the means 
Appendix 2: Household decision-making in the IFLS4

As noted previously, the IFLS4 contained 18 types of decisions. There were:

- Expenditure on food eaten at home;

- Choice of food eaten at home;

- Routine household purchases;

- The respondent's clothes;

- The respondent's spouse's clothes;

- The respondent's children's clothes;

- The respondent's children's education;

- The respondent's children's health;

- Large expensive household purchases;

- Giving money to the respondent's parents or family;

- Giving money to the respondent's spouse's parents or family;

- Giving gifts for parties or weddings;

- Using money for monthly ROSCA (Arisan);

- Using money for monthly savings;

- Husband's time spent socializing;

- Wife's time spent socializing;

- Whether the respondent or the respondent's spouse works;

- Whether the respondent and spouse use contraception.

In addition to the large number of decisions, there were also 16 different choices of decisionmakers: 
- Respondent;

- Spouse;

- Son;

- Daughter;

- Mother;

- Father;

- Mother-in-law;

- Father-in-law;

- Brother;

- Sister;

- Brother-in-law;

- Sister-in-law;

- Grandparent;

- Son/daughter-in-law;

- Grandchild; and

- Other.

\section{Creating the decision-making variables}

We started by creating a dummy variable for each decision and decision-maker in the groups in Table 5. To illustrate, let us consider decisions relating to children. Three dummy variables were created for each child related decision (children's health, children's education and children's clothes) for each of the four decision-makers (respondent, spouse, joint or other). In other words, 12 dummy variables were created. Then, the three child-related decisions were added together and normalized to proportions of one for each decision-maker. Thus, the respondent might make only one childrelated decision alone in which case this variable would be one-third for them or they might make all 
three decisions alone (in which case the variable would be one). To create our overall measure of direct agency, we use simple aggregation of all the different decision-making spheres for each decision-maker. 
Tables to be inserted into main text

Table 1 Subjective well-being by gender

\begin{tabular}{|c|c|c|c|}
\hline \multirow[t]{2}{*}{ Subjective well-being score } & \multicolumn{2}{|c|}{ Gender } & \multirow{2}{*}{ Total } \\
\hline & Men & Women & \\
\hline Very unhappy & 41 & 46 & 87 \\
\hline Unhappy & 1,229 & 1,185 & 2,414 \\
\hline Happy & 11,754 & 12,970 & 24,724 \\
\hline Very happy & 813 & 1,017 & 1,830 \\
\hline Total & 13,837 & 15,218 & 29,055 \\
\hline
\end{tabular}

Table 2 Descriptive statistics for continuous control variables

\begin{tabular}{|c|c|c|c|c|c|}
\hline \multirow[t]{2}{*}{ Variable } & \multirow[t]{2}{*}{ Definition } & \multicolumn{2}{|c|}{ Men } & \multicolumn{2}{|c|}{ Women } \\
\hline & & Mean & $\begin{array}{l}\text { Std. } \\
\text { Dev. }\end{array}$ & Mean & $\begin{array}{l}\text { Std. } \\
\text { Dev. }\end{array}$ \\
\hline Age & $\begin{array}{l}\text { Respondent's } \\
\text { age at the } \\
\text { time of IFLS4 }\end{array}$ & 30.7433 & 20.8596 & 31.6945 & 21.4489 \\
\hline Log of household income ${ }^{1}$ & $\begin{array}{l}\text { Log of } \\
\text { household } \\
\text { income in } \\
\text { the last year }\end{array}$ & 16.1973 & 1.1530 & 16.1693 & 1.1985 \\
\hline
\end{tabular}




\begin{tabular}{|c|c|c|c|c|c|}
\hline Household size & $\begin{array}{l}\text { Number of } \\
\text { household } \\
\text { members } \\
\text { excluding } \\
\text { young, non- } \\
\text { school age } \\
\text { children }\end{array}$ & 6.6641 & 3.4625 & 6.6739 & 3.4904 \\
\hline Young children (number) & $\begin{array}{l}\text { Number of } \\
\text { young, non- } \\
\text { school age } \\
\text { children in } \\
\text { the } \\
\text { household }\end{array}$ & 0.1237 & 0.3741 & 0.1268 & 0.3780 \\
\hline Social capital proxy: cooperation ${ }^{2}$ & $\begin{array}{l}\text { Respondent's } \\
\text { willingness } \\
\text { to help } \\
\text { people in } \\
\text { his/her } \\
\text { village }\end{array}$ & 3.1747 & 0.4032 & 3.1285 & 0.3611 \\
\hline Social capital proxy: security ${ }^{2}$ & $\begin{array}{l}\text { Respondents' } \\
\text { views on } \\
\text { village safety }\end{array}$ & 3.0798 & 0.3814 & 3.0615 & 0.3621 \\
\hline Spouse's well-being & $\begin{array}{l}\text { Well-being of } \\
\text { respondent's } \\
\text { spouse }\end{array}$ & 2.9978 & 0.3752 & 2.9709 & 0.3930 \\
\hline
\end{tabular}


1 Note that these are small amounts of c. $£ 500-f 700$. This is based on an exchange rate of Rupiah (Rp.) 18,928

to $f 1$ which was the spot rate as at 14 March 2014

2 Note that this is a scale from 1 to 4 where $1=$ strongly disagree and 4=strongly agree

Table 3 Descriptive statistics for dummy control variables

\begin{tabular}{|c|c|c|c|c|c|}
\hline \multirow[t]{2}{*}{ Variables } & \multirow[t]{2}{*}{ Definition } & \multicolumn{2}{|c|}{ Men } & \multicolumn{2}{|c|}{ Women } \\
\hline & & Mean & Std. Dev. & Mean & Std. Dev. \\
\hline Christianity $^{1}$ & $\begin{array}{l}\text { Christian=1, } \\
\text { Else }=0\end{array}$ & 0.0650 & 0.2466 & 0.0655 & 0.2474 \\
\hline Other religion ${ }^{1}$ & $\begin{array}{l}\text { Other } \\
\text { religions=1, } \\
\text { Christian or } \\
\text { Muslim=0 }\end{array}$ & 0.0486 & 0.2150 & 0.0496 & 0.2172 \\
\hline Ethnicity: Sundanese ${ }^{2}$ & $\begin{array}{l}\text { Sundanese=1, } \\
\text { Else }=0\end{array}$ & 0.1229 & 0.3283 & 0.1222 & 0.3275 \\
\hline Ethnicity: Batak ${ }^{2}$ & Batak $=1$, Else $=0$ & 0.0463 & 0.2102 & 0.0468 & 0.2112 \\
\hline Ethnicity: Minangkabau² & $\begin{array}{l}\text { Minangkabau=1, } \\
\text { Else }=0\end{array}$ & 0.0452 & 0.2077 & 0.0446 & 0.2065 \\
\hline Ethnicity: Other ethnicities ${ }^{2}$ & $\begin{array}{l}\text { Other } \\
\text { ethnicities=1, } \\
\text { Javanese, } \\
\text { Sundanese, } \\
\text { Batak or } \\
\text { Minangkabau=0 }\end{array}$ & 0.3837 & 0.4863 & 0.3826 & 0.4860 \\
\hline
\end{tabular}




\begin{tabular}{|c|c|c|c|c|c|}
\hline Secondary education & $\begin{array}{l}\text { Up to secondary } \\
\text { education=1, } \\
\text { Else=0 }\end{array}$ & 0.4398 & 0.4964 & 0.3817 & 0.4858 \\
\hline Higher education & $\begin{array}{l}\text { Up to higher } \\
\text { education=1, } \\
\text { Else=0 }\end{array}$ & 0.0884 & 0.2839 & 0.0780 & 0.2681 \\
\hline Islamic education & $\begin{array}{l}\text { Islamic } \\
\text { education=1, } \\
\text { Else=0 }\end{array}$ & 0.0586 & 0.2349 & 0.0671 & 0.2502 \\
\hline Ownership of own house & $\begin{array}{l}\text { Ownership of } \\
\text { own house=1, } \\
\text { Else=0 }\end{array}$ & 0.7642 & 0.4245 & 0.7770 & 0.4163 \\
\hline Use of loans in the last 12 months & $\begin{array}{l}\text { Use of loans }=1 \text {, } \\
\text { Else }=0\end{array}$ & 0.1883 & 0.3910 & 0.1835 & 0.3871 \\
\hline Community facilities: electricity & $\begin{array}{l}\text { Community has } \\
\text { electricity=1, } \\
\text { Else }=0\end{array}$ & 1.0064 & 0.1199 & 1.0064 & 0.1317 \\
\hline Community facilities: health & $\begin{array}{l}\text { Community has } \\
\text { midwife=1, } \\
\text { Else }=0\end{array}$ & 1.5101 & 0.8718 & 1.5157 & 0.8749 \\
\hline Household has electricity & $\begin{array}{l}\text { Household has } \\
\text { electricity=1, } \\
\text { Else=0 }\end{array}$ & 1.0754 & 0.3873 & 1.0741 & 0.3861 \\
\hline
\end{tabular}

1 The majority of the population in Indonesia is Muslim which is the base category used here 
2 Note that the largest ethnic group in Indonesia is the Javanese. They are used as the base category. In our paper we include the four largest ethnic groups which range from patriarchal and patrilineal (Batak) to bilateral (Javanese) to matrilineal (Minangkabau)

Table 4 Descriptive statistics for relative income, age and education

\begin{tabular}{|l|c|c|}
\hline VARIABLES & \multicolumn{2}{|c|}{ Descriptive statistics } \\
\cline { 2 - 3 } & Mean & 0.2148 \\
\hline Relative income (men) & 0.618 & 0.2148 \\
\hline Relative income (women) & 0.382 & 22.39 \\
\hline Relative education (men) & 4,716 & 11.96 \\
\hline Relative education (women) & 2,660 & 0.157 \\
\hline Relative age (men) & & 0.113 \\
\hline Relative age (women) & 1.14 & \\
\hline
\end{tabular}

Table 5 Descriptive statistics for the decision-making variables

\begin{tabular}{|c|c|c|c|c|}
\hline \multirow[t]{2}{*}{ Variable } & \multicolumn{2}{|c|}{ Men } & \multicolumn{2}{|c|}{ Women } \\
\hline & Mean & Std. Dev. & Mean & $\begin{array}{l}\text { Std. } \\
\text { Dev. }\end{array}$ \\
\hline Proportion of child related decisions made by spouse & 0.1395 & 0.2700 & 0.0337 & 0.1467 \\
\hline Proportion of child related decisions made jointly & 0.6947 & 0.3922 & 0.7075 & 0.3828 \\
\hline Proportion of child related decisions made by others & 0.0380 & 0.1565 & 0.0441 & 0.1588 \\
\hline $\begin{array}{l}\text { Proportion of large household expenditure decisions made } \\
\text { by spouse }\end{array}$ & 0.0696 & 0.2545 & 0.0954 & 0.2938 \\
\hline Proportion of large household expenditure decisions made & 0.7659 & 0.4234 & 0.7906 & 0.4069 \\
\hline
\end{tabular}




\begin{tabular}{|c|c|c|c|c|}
\hline jointly & & & & \\
\hline $\begin{array}{l}\text { Proportion of large household expenditure decisions made } \\
\text { by others }\end{array}$ & 0.0473 & 0.2123 & 0.0513 & 0.2206 \\
\hline Proportion of cash giving and gift decisions made by spouse & 0.0730 & 0.2060 & 0.0452 & 0.1685 \\
\hline Proportion of cash giving and gift decisions made jointly & 0.8070 & 0.3341 & 0.8194 & 0.3239 \\
\hline Proportion of cash giving and gift decisions made by others & 0.0033 & 0.0431 & 0.0050 & 0.0504 \\
\hline Proportion of savings decisions made by spouse & 0.1175 & 0.2643 & 0.0298 & 0.1339 \\
\hline Proportion of savings decisions made jointly & 0.3254 & 0.3981 & 0.3258 & 0.3969 \\
\hline Proportion of savings decisions made by others & 0.0077 & 0.0686 & 0.0103 & 0.0823 \\
\hline $\begin{array}{l}\text { Proportion of small household expenditure decisions made } \\
\text { by spouse }\end{array}$ & 0.6360 & 0.4347 & 0.0670 & 0.2231 \\
\hline $\begin{array}{l}\text { Proportion of small household expenditure decisions made } \\
\text { jointly }\end{array}$ & 0.2532 & 0.3885 & 0.2490 & 0.3888 \\
\hline $\begin{array}{l}\text { Proportion of small household expenditure decisions made } \\
\text { by others }\end{array}$ & 0.0390 & 0.1806 & 0.0992 & 0.2824 \\
\hline Proportion of all household decisions made by spouse & 0.2012 & 0.1761 & 0.0476 & 0.1138 \\
\hline Proportion of all household decisions made jointly & 0.5849 & 0.2444 & 0.5934 & 0.2390 \\
\hline Proportion of all household decisions made by others & 0.0240 & 0.0746 & 0.0380 & 0.0915 \\
\hline Respondent only decision: use of own leisure time & 0.4349 & 0.4958 & 0.3359 & 0.4723 \\
\hline
\end{tabular}


Table 6 Subjective well-being ordered probit models - agency proxy results

\begin{tabular}{|c|c|c|c|c|c|c|c|c|}
\hline \multirow[t]{3}{*}{ Variables } & \multicolumn{4}{|c|}{ Whole sample } & \multicolumn{4}{|c|}{ Couples } \\
\hline & \multicolumn{2}{|c|}{ Model 1} & \multicolumn{2}{|c|}{ Model 2} & \multicolumn{2}{|c|}{ Model 3} & \multicolumn{2}{|c|}{ Model 4} \\
\hline & Men & Women & Men & Women & Men & Women & Men & Women \\
\hline Relative income & $\begin{array}{c}-0.7559 \\
{[0.582]}\end{array}$ & $\begin{array}{l}0.3228 \\
{[0.408]}\end{array}$ & & & & & & \\
\hline Relative income ${ }^{2}$ & $\begin{array}{l}0.6204 \\
{[0.484]}\end{array}$ & $\begin{array}{c}-0.0608 \\
{[0.485]}\end{array}$ & & & & & & \\
\hline Relative age & $\begin{array}{l}0.2854 \\
{[0.180]}\end{array}$ & $\begin{array}{l}0.4326 * \\
{[0.249]}\end{array}$ & & & & & & \\
\hline Relative education & $\begin{array}{c}-0.1779 * * \\
{[0.070]}\end{array}$ & $\begin{array}{l}-0.0887 \\
{[0.077]}\end{array}$ & & & & & & \\
\hline Proportion of child related decisions made by spouse & & & $\begin{array}{c}-0.17496 * * \\
{[0.078]}\end{array}$ & $\begin{array}{l}0.03880 \\
{[0.121]}\end{array}$ & $\begin{array}{l}-0.0297 \\
{[0.071]}\end{array}$ & $\begin{array}{l}0.0832 \\
{[0.105]}\end{array}$ & & \\
\hline Proportion of child related decisions made jointly & & & $\begin{array}{c}-0.11450 * * \\
{[0.055]}\end{array}$ & $\begin{array}{c}-0.04999 \\
{[0.049]}\end{array}$ & $\begin{array}{l}-0.0071 \\
{[0.054]}\end{array}$ & $\begin{array}{l}0.0008 \\
{[0.047]}\end{array}$ & & \\
\hline Proportion of child related decisions made by others & & & 0.06023 & 0.11822 & 0.0725 & 0.1133 & & \\
\hline
\end{tabular}




\begin{tabular}{|c|c|c|c|}
\hline [0.116] & [0.114] & [0.106] & [0.102] \\
\hline 0.04699 & -0.05733 & 0.0279 & -0.0408 \\
\hline [0.082] & [0.092] & [0.067] & [0.076] \\
\hline 0.06104 & 0.06028 & 0.0382 & 0.0080 \\
\hline [0.054] & [0.076] & [0.047] & [0.064] \\
\hline 0.06189 & 0.00620 & 0.0822 & -0.1699 \\
\hline [0.096] & [0.104] & [0.092] & [0.108] \\
\hline$-0.21256^{* *}$ & 0.16208 & -0.1197 & 0.0431 \\
\hline [0.105] & [0.134] & [0.088] & [0.104] \\
\hline 0.07926 & $0.23980 * * *$ & 0.0252 & 0.0797 \\
\hline [0.069] & [0.067] & [0.058] & [0.059] \\
\hline-0.03870 & 0.00667 & 0.0413 & 0.0522 \\
\hline$[0.288]$ & [0.303] & [0.534] & [0.389] \\
\hline $0.22071^{* * *}$ & $0.53339 * * *$ & $0.1001 *$ & $0.2245^{* *}$ \\
\hline$[0.062]$ & [0.132] & {$[0.056]$} & {$[0.106]$} \\
\hline $0.24057^{* * *}$ & $0.12519 * * *$ & $0.1312^{* * *}$ & 0.0114 \\
\hline$[0.042]$ & [0.041] & [0.039] & [0.038] \\
\hline-0.04548 & 0.05968 & -0.1113 & 0.0977 \\
\hline [0.208] & [0.177] & [0.254] & [0.202] \\
\hline $0.13945^{* *}$ & 0.00745 & 0.0648 & 0.0225 \\
\hline
\end{tabular}




\begin{tabular}{|c|c|c|c|c|c|}
\hline [0.071] & [0.070] & [0.061] & [0.063] & & \\
\hline 0.03399 & -0.03647 & 0.0026 & -0.0163 & & \\
\hline [0.078] & [0.041] & [0.067] & [0.037] & & \\
\hline 0.16992 & 0.06466 & 0.1337 & 0.0149 & & \\
\hline [0.113] & [0.063] & [0.172] & {$[0.086]$} & & \\
\hline $0.09245^{* * *}$ & -0.03538 & $0.0551 *$ & -0.0206 & $0.0566 * *$ & -0.0192 \\
\hline \multirow[t]{9}{*}{ [0.031] } & [0.032] & [0.028] & {$[0.030]$} & [0.028] & [0.030] \\
\hline & & $1.8625^{* * *}$ & $1.8567 * * *$ & $1.8669 * * *$ & $1.8594 * * *$ \\
\hline & & [0.037] & [0.037] & [0.037] & [0.037] \\
\hline & & & & $0.1702 *$ & 0.2006 \\
\hline & & & & [0.103] & [0.129] \\
\hline & & & & $0.2398 * * *$ & 0.0857 \\
\hline & & & & [0.081] & [0.070] \\
\hline & & & & $0.4637^{*}$ & 0.0917 \\
\hline & & & & [0.264] & [0.209] \\
\hline-0.45798 & $-0.81876^{* *}$ & $3.6054 * * *$ & $3.3144 * * *$ & $3.6877^{* * *}$ & $3.3271 * * *$ \\
\hline$[0.336]$ & [0.354] & [0.430] & [0.437] & [0.424] & [0.431] \\
\hline $0.97172 * * *$ & 0.55106 & $5.1786 * * *$ & $4.8728 * * *$ & $5.2563^{* * *}$ & $4.8761 * * *$ \\
\hline
\end{tabular}


cut3

Constant

Observations

Log likelihood

LR Chi2

pseudo r-squared

\begin{tabular}{|c|c|c|c|c|c|}
{$[0.334]$} & {$[0.354]$} & {$[0.428]$} & {$[0.433]$} & {$[0.421]$} & {$[0.426]$} \\
& & & & & \\
\hline $.06657 * * *$ & $3.71956^{* * *}$ & $7.92786 * * *$ & $7.66219 * * *$ & $7.99542^{* * *}$ & $7.65535 * * *$ \\
{$[0.339]$} & {$[0.359]$} & {$[0.431]$} & {$[0.437]$} & {$[0.425]$} & {$[0.430]$} \\
& & -1.6225 & -1.6225 & -1.6225 & -1.6225 \\
& & {$[0.000]$} & {$[0.000]$} & {$[0.000]$} & {$[0.000]$} \\
8,930 & 9,378 & 7,759 & 7,759 & 7,759 & 7,759 \\
-4427 & -4383 & -5840 & -5840 & -5854 & -5854 \\
458.6 & 411.0 & 3630 & 3630 & 3602 & 3602 \\
0.0585 & 0.0543 &. &. &. &. \\
\hline
\end{tabular}

Standard errors in brackets ${ }^{* * *} p<0.001,{ }^{* *} p<0.05,{ }^{*} p<0.1$

Dependent variable is subjective well-being where $1=$ =very unhappy; $2=$ unhappy; $3=$ happy; and 4=very happy

Control variables include age, religion, ethnicity, education level, ownership of own home, use of loans in last 12 months, spousal well-being, household and community characteristics and social capital proxies (cooperation and security)

Models 1 and 2 are estimated using ordered probits

Models 3 and 4 are estimated using Seemingly Unrelated Regression ordered probits 


\section{References}

Abadian, S. (1996). Women's autonomy and its impact on fertility. World Development, 24(12), 1793-1809. doi: http://dx.doi.org/10.1016/S0305-750X(96)00075-7

Abrams, K. (1998). From Autonomy to Agency: Feminist Perspectives on Self-Direction. William and Mary Law Review, 40, 805.

Adato, M., Brière, B. d. I., Mindek, D., \& Quisumbing, A. R. (2003). The Impact of PROGRESA on Women's Status and Intrahousehold Relations. In A. R. Quisumbing (Ed.), Household Decisions, Gender, and Development A Synthesis of Recent Research (pp. 213-218). Washington D.C.: International Food Policy Research Institute.

Agarwal, B. (1997). "Bargaining" and Gender Relations: Within and Beyond the Household. Feminist Economics, 3(1), 1-51. doi: 10.1080/135457097338799

Anderson, S., \& Eswaran, M. (2009). What determines female autonomy? Evidence from Bangladesh. Journal of Development Economics, 90(2), 179-191.

Argyle, M. (2003). Causes and Correlates of Happiness. In D. Kahneman, E. Diener \& N. Schwarz (Eds.), Well-being The Foundations of Hedonic Psychology (pp. 606). New York: Russell Sage Foundation.

Ashraf, N. (2009). Spousal Control and Intra-Household Decision Making: An Experimental Study in the Philippines. American Economic Review, 99(4), 1245-1277.

Basu, K. (2006). Gender and Say: A Model of Household Behaviour with Endogenously Determined Balance of Power. Economic Journal, 116(511), 558-580. doi: 10.1111/j.14680297.2006.01092.x 
Benda-Beckmann, K. v., \& Benda-Beckmann, F. v. (2000). Houses, People and Residence: The Fluidity of Ambonese Living Arrangements. In J. Koning, M. Nolten, J. Rodenburg \& R. Saptari (Eds.), Women and households in Indonesia : cultural notions and social practices (pp. 102-141). Richmond, Surrey: Curzon.

Bertrand, M., Kamenica, E., \& Pan, J. (2013). Gender identity and relative income within households.

Bittman, M., England, P., Folbre, N., Sayer, L., \& Matheson, G. (2003). When does Gender Trump Money? Bargaining and Time in Household Work. The American Journal of Sociology, 109(1), 186-214.

Black, L. (1994). The 'White Negro' revisited: Race and Masculinities in south London. In A. Cornwall \& N. Lindisfarne (Eds.), Dislocating masculinity Comparative ethnographies. London: Routledge.

Blackburn, S. (2004). Women And The State In Modern Indonesia: Cambridge University Press.

Blackwood, E. (1995). Senior Women, Model Mothers, and Dutiful Wives: Managing Gender Contradictions in a Minangkabau Village. In A. Ong \& M. G. Peletz (Eds.), Bewitching women, pious men : gender and body politics in Southeast Asia (pp. x, 309 p). Berkeley: University of California Press.

Blackwood, E. (2007). Not Your Average Housewife Minangkabau Women Rice Farmers in West Sumatra. In M. Ford \& L. Parker (Eds.), Women and work in Indonesia (pp. 17-40). London: Routledge.

Blumberg, R. (1988). Income under Female versus Male Control - Hypotheses from a Theory of Gender Stratification and Data from the Third-World. Journal of Family Issues, 9(1), 51-84. 
Bookwalter, J. T., \& Dalenberg, D. R. (2010). Relative to What or Whom? The Importance of Norms and Relative Standing to Well-Being in South Africa. World Development, 38(3), 345-355.

Brenner, S. A. (1995). Why Women Rule the Roost: Rethinking Javanese Ideologies of Gender and Self-Control. In A. Ong \& M. G. Peletz (Eds.), Bewitching women, pious men : gender and body politics in Southeast Asia (pp. x, 309 p). Berkeley: University of California Press.

Bulbeck, C. (1997). Re-orienting Western Feminisms: Women's Diversity in a Postcolonial World: Cambridge University Press.

Buttenheim, A. M., \& Nobles, J. (2009). Ethnic diversity, traditional norms, and marriage behaviour in Indonesia. Population Studies, 63(3), 277-294. doi: 10.1080/00324720903137224

Cassidy, G. L., \& Davies, L. (2003). Explaining Gender Differences in Mastery among Married Parents. Social Psychology Quarterly, 66(1), 48-61.

Clark, A., Knabe, A., \& Ratzel, S. (2010). Boon or bane? Others' unemployment, well-being and job insecurity. Labour Economics, 17(1), 52-61. doi: 10.1016/j.labeco.2009.05.007

Cornwall, A., Harrison, E., \& Whitehead, A. (2007). Gender Myths and Feminist Fables: The Struggle for Interpretive Power in Gender and Development. Development and Change, 38(1), 1-20.

Dasgupta, I. (2001). Gender-biased redistribution and intra-household distribution. European Economic Review, 45(9), 1711-1722.

Dawson, G. (2007). Keeping Rice in the Pot: Women and Work in a Transmigration Settlement. In M. Ford \& L. Parker (Eds.), Women and work in Indonesia (pp. 41-60). London: Routledge. 
de Brauw, A., Gilligan, D. O., Hoddinott, J., \& Roy, S. (2014). The Impact of Bolsa Família on Women's Decision-Making Power. World Development, 59(0), 487-504. doi: http://dx.doi.org/10.1016/j.worlddev.2013.02.003

Della Giusta, M., Jewell, S. L., \& Kambhampati, U. S. (2011). Gender and Life Satisfaction in the UK. Feminist Economics, 17(3), 1-34. doi: 10.1080/13545701.2011.582028

Diener, E., Ng, W., Harter, J., \& Arora, R. (2010). Wealth and Happiness Across the World: Material Prosperity Predicts Life Evaluation, Whereas Psychosocial Prosperity Predicts Positive Feeling. Journal of Personality and Social Psychology, 99(1), 52-61.

Diener, E., \& Suh, E. M. (2000). Culture and subjective well-being. Cambridge, Mass.: MIT Press.

Dolan, P., Peasgood, T., \& White, M. (2008). Do we really know what makes us happy A review of the economic literature on the factors associated with subjective well-being. Journal of Economic Psychology, 29(1), 94-122.

Duflo, E. (2012). Women Empowerment and Economic Development. Journal of Economic Literature, 50(4), 1051-1079.

Easterlin, R. A. (2001). Income and Happiness: Towards a Unified Theory. The Economic Journal, $111(473), 465-484$.

Easterlin, R. A., Angelescu, L., \& Zweig, J. S. (2011). The Impact of Modern Economic Growth on Urban-Rural Differences in Subjective Well-Being. World Development, 39(12), 2187-2198. doi: http://dx.doi.org/10.1016/j.worlddev.2011.04.015

Elmhirst, R. (2000). Negotiating Gender, Kinship and Livelihood Practices in an Indonesian Transmigration Area. In J. Koning, M. Nolten, J. Rodenburg \& R. Saptari (Eds.), Women and 
households in Indonesia : cultural notions and social practices (pp. 208-232). Richmond, Surrey: Curzon.

England, P. (1993). The Separative Self: Andocentric Bias in Neoclassical Assumptions. In M. A. Ferber \& J. A. Nelson (Eds.), Beyond Economic Man Feminist Theory and Economics (pp. 3753). Chicago: The University of Chicago Press.

Fast, N. J., Gruenfeld, D. H., Sivanathan, N., \& Galinsky, A. D. (2009). Illusory Control : A Generative Force Behind Power's Far-Reaching Effects. Psychological Science, 20.

Felkey, A. J. (2013). Husbands, Wives and the Peculiar Economics of Household Public Goods. European Journal of Development Research, 25(3), 445-465.

Ferrer-i-Carbonell, A., \& Frijters, P. (2004). How Important is Methodology for the Estimates of the Determinants of Happiness? The Economic Journal, 114, 641-659.

Folbre, N. (1994a). Children as Public Goods. The American Economic Review, 84(2), 86-90.

Folbre, N. (1994b). Who Pays for the Kids? Gender and the Structures of Constraint. London: Routledge.

Fontaine, X., \& Yamada, K. (2014). Caste Comparisons in India: Evidence From Subjective Well-Being Data. World Development, 64(0), 407-419. doi: http://dx.doi.org/10.1016/i.worlddev.2014.06.025

Frankenberg, E., Karoly, L. A., Gertler, P., Achmad, S., Agung, I. G. N., Hatmadji, S. H., \& Sudharto, P. (1995). The 1993 Indonesian Family Life Survey: Overview and Field Report. . Santa Monica, CA: RAND Corporation. 
Frankenberg, E., \& Thomas, D. (2001). Measuring power: Food Consumption and Nutrition Division, International Food Policy Research Institute.

Frey, B. S., \& Stutzer, A. (2002). Happiness and economics : how the economy and institutions affect well-being. Princeton, N.J. Oxfordshire: Princeton University Press.

Friedman, M. (2000). Autonomy, Social Disruption, and Women. In C. Mackenzie \& N. Stoljar (Eds.), Relational autonomy : feminist perspectives on automony, agency, and the social self ( $\mathrm{pp} . \mathrm{xi}$, 314 p). New York ; Oxford: Oxford University Press.

Garikipati, S. (2008). The Impact of Lending to Women on Household Vulnerability and Women's Empowerment: Evidence from India. World Development, 36(12), 2620-2642.

Greenstein, T. N. (1995). Gender Ideology, Marital Disruption, and the Employment of Married Women. Journal of Marriage and Family, 57(1), 31-42.

Greenstein, T. N. (2000). Economic Dependence, Gender, and the Division of Labor in the Home: A Replication and Extension. Journal of Marriage and Family, 62(2), 322-335.

Grob, A. (2000). Perceived Control and Subjective Well-being across Nations and across the Life Span. In E. Diener \& E. M. Suh (Eds.), Culture and subjective well-being (pp. [ix], 355 p.). Cambridge, Mass. ; London: MIT Press.

Grote, N. K., Bledsoe, S. E., Larkin, J., Lemay, E. P., \& Brown, C. (2007). Stress Exposure and Depression in Disadvantaged Women: The Protective Effects of Optimism and Perceived Control. Social Work Research, 31(1), 19-33.

Gupta, S. (2006). Her money, her time: Women's earnings and their housework hours. Social Science Research, 35(4), 975-999. 
Hoddinott, J., \& Haddad, L. (1991). Household Expenditure, Child Anthropometric Status and the Intra-household Division of Income: Evidence from the Cote d'Ivoire Woodrow Wilson School Working Paper: Princeton University and Trinity College, Oxford.

Hoddinott, J., \& Haddad, L. (1995). Does Female Income Share Influence Household Expenditures? Evidence from Cote D'Ivoire. Oxford Bulletin of Economics \& Statistics, 57(1), 77-96.

Iversen, V. (2003). Intra-household inequality: A challenge for the capability approach? Feminist Economics, 9(2-3), 93-115. doi: 10.1080/1354570032000080868

Jejeebhoy, S. J. (2002). Convergence and Divergence in Spouses' Perspectives on Women's Autonomy in Rural India. Studies in Family Planning, 33(4), 299-308.

Jiang, S., Lu, M., \& Sato, H. (2012). Identity, Inequality, and Happiness: Evidence from Urban China. World Development, 40(6), 1190-1200. doi: http://dx.doi.org/10.1016/i.worlddev.2011.11.002

Jones, G. W. (2002). The Changing Indonesian Household. In K. Robinson \& S. Bessell (Eds.), Women in Indonesia: Gender, Equity and Development (pp. 219-234). Singapore: Institute of Southeast Asian Studies

Jufri, M., \& Watson, C. W. (1998). Decision-making in rural households in Kerinci and Minangkabau. Indonesia and the Malay World, 26(74), 13-31. doi: 10.1080/13639819808729908

Kabeer, N. (1994). Reversed realities : gender hierarchies in development thought. London ; New York: Verso.

Kabeer, N. (1997). Women, Wages and Intra-household Power Relations in Urban Bangladesh. Development and Change, 28(2), 261-302. doi: 10.1111/1467-7660.00043 
Kabeer, N. (1998). Money Can't Buy Me Love? Re-evaluating Gender, Credit and Empowerment in Rural Bangladesh IDS Discussion Paper Brighton: Institute of Development Studies.

Kabeer, N. (1999). Resources, agency, achievements: reflections on the measurement of women's empowerment. Development and Change, 30(3), 435-464.

Kahneman, D., Diener, E., \& Schwarz, N. (Eds.). (2003). Well-being The Foundations of Hedonic Psychology. New York: Russell Sage Foundation.

Kambhampati, U. S. (2009). Child schooling and work decisions in India: the role of household and regional gender equity. Feminist Economics, 15(4), 77-112.

Kandiyoti, D. (1988). Bargaining with Patriarchy. Gender and Society, 2(3), 274-290.

Kandiyoti, D. (1994). The paradoxes of masculinity: Some thoughts on segregated societies. In A. Cornwall \& N. Lindisfarne (Eds.), Dislocating masculinity Comparative ethnographies. London: Routledge.

Kenny, A. J. P., \& Kenny, C. (2006). Life, liberty, and the pursuit of utility : happiness in philosophical and economic thought. Exeter: Imprint Academic.

Knight, J., \& Gunatilaka, R. (2010). Great Expectations? The Subjective Well-being of Rural-Urban Migrants in China. World Development, 38(1), 113-124. doi: http://dx.doi.org/10.1016/i.worlddev.2009.03.002

Koning, J. (2000). Different Times, Different Orientations: Family Life in a Javanese Village. In J. Koning, M. Nolten, J. Rodenburg \& R. Saptari (Eds.), Women and households in Indonesia : cultural notions and social practices (pp. 181-207). Richmond, Surrey: Curzon. 
Koning, J., Nolten, M., Rodenburg, J., \& Saptari, R. (Eds.). (2000). Women and households in Indonesia : cultural notions and social practices. Richmond, Surrey: Curzon.

Kreager, P., \& Schroder-Butterfill, E. (2009). Ageing and Gender Preferences in Rural Indonesia CRA Discussion Paper (Vol. CRA DP/0905). Southampton: Centre for Research on Ageing School of Social Sciences.

Kreager, P., \& Schröder-Butterfill, E. (2005). Ageing Without Children: European And Asian Perspectives: Berghahn Books, Incorporated.

Krier, J. (1995). Narrating Herself: Power and Gender in a Minangkabau Woman's Tale of Conflict. In A. Ong \& M. G. Peletz (Eds.), Bewitching women, pious men : gender and body politics in Southeast Asia (pp. x, 309 p). Berkeley: University of California Press.

Kritz, M. M., \& Makinwa-Adebusoye, P. (1999). Determinants of Women's Decision-Making Authority in Nigeria: The Ethnic Dimension. Sociological Forum, 14(3), 399-424.

Layard, P. R. G. (2006). Happiness : lessons from a new science. New York: Penguin.

Lundberg, S., \& Pollak, R. A. (1993). Separate Spheres Bargaining and the Marriage Market. The Journal of Political Economy, 101(6), 988-1010.

Mabsout, R., \& van Staveren, I. (2009). Disentangling Bargaining Power from Individual and Household Level to Institutions: Evidence on Women's Position in Ethiopia. World Development, In Press, Corrected Proof.

Moser, C. O. N. (1989). Gender planning in the third world: Meeting practical and strategic gender needs. World Development, 17(11), 1799-1825. doi: http://dx.doi.org/10.1016/0305750X(89)90201-5 
Myers, D. C. (2003). Close Relationships and Quality of Life. Well-Being: Foundations of Hedonic Psychology, 374.

Nolten, M. (2000). Food for Thought Reflections on the Conference and the Set-up of this Book. In J. Koning, M. Nolten, J. Rodenburg \& R. Saptari (Eds.), Women and households in Indonesia : cultural notions and social practices (pp. 3-9). Richmond, Surrey: Curzon.

O'Shaughnessy, K. (2009). Gender, State and Social Power in Contemporary Indonesia : Divorce and Marriage Law. London; New York: Routledge.

Oey-Gardiner, M. (2002). And the Winner is...Indonesian Women in Public Life. In K. Robinson \& S. Bessell (Eds.), Women in Indonesia: Gender, Equity and Development (pp. 100-112). Singapore: Institute of Southeast Asian Studies

Ono, H., \& Raymo, J. M. (2006). Housework, market work, and "doing gender" when marital satisfaction declines. Social Science Research, 35(4), 823-850.

Park, C. (2003). Interhousehold Transfers between Relatives in Indonesia: Determinants and Motives. Economic Development and Cultural Change, 51(4), 929-944. doi: 10.1086/375014

Peter, F. (2003). Gender and the Foundations of Social Choice: The Role of Situated Agency. Feminist Economics, 9(2-3), 13-32. doi: 10.1080/1354570022000078006

Quisumbing, A. R. (Ed.). (2003). Household Decisions, Gender, and Development A Synthesis of Recent Research. Washington D.C.: International Food Policy Research Institute.

Quisumbing, A. R., \& Maluccio, J. A. (2003). Resources at Marriage and Intrahousehold Allocation: Evidence from Bangladesh, Ethiopia, Indonesia, and South Africa. Oxford Bulletin of Economics and Statistics, 65(3), 283-327. doi: 10.1111/1468-0084.t01-1-00052 
Rammohan, A., \& Johar, M. (2009). The Determinants of Married Women's Autonomy in Indonesia. Feminist Economics, 15(4), 31 - 55.

Reenen, J. v. (2000). The Salty Mouth of a Senior Woman: Gender and the House in Minangkabau. In J. Koning, M. Nolten, J. Rodenburg \& R. Saptari (Eds.), Women and households in Indonesia : cultural notions and social practices. Richmond, Surrey: Curzon

Richter, K. (2009). Changes in Subjective Well-Being in Timor-Leste on the Path to Independence. World Development, 37(2), 371-384. doi: http://dx.doi.org/10.1016/j.worlddev.2008.03.007

Rosenfield, S. (1989). The Effects of Women's Employment: Personal Control and Sex Differences in Mental Health. Journal of Health and Social Behavior, 30(1), 77-91. doi: 10.2307/2136914

Rosenfield, S. (1999). Splitting the Difference. In C. Aneshensel \& J. Phelan (Eds.), Handbook of the Sociology of Mental Health (pp. 209-224): Springer US.

Rosenfield, S., \& Mouzon, D. (2013). Gender and Mental Health. In C. Aneshensel, J. Phelan \& A. Bierman (Eds.), Handbook of the Sociology of Mental Health (pp. 277-296): Springer Netherlands.

Sakai, M. (2010). Growing together in partnership: Women's views of the business practices of an Islamic Savings and Credit Cooperative (Baitul Maal wat Tamwil) in Central Java, Indonesia. Women's Studies International Forum, 33(4), 412-421.

Sanday, P. R. (2002). Women at the Center : Life in a Modern Matriarchy. Ithaca, N.Y. ; London: Cornell University Press.

Saptari, R. (2000). Women, Family and Household: Tensions in Culture and Practice. In J. Koning, M. Nolten, J. Rodenburg \& R. Saptari (Eds.), Women and households in Indonesia : cultural notions and social practices (pp. 10-27). Richmond, Surrey: Curzon. 
Schroder-Butterfill, E., \& Kreager, P. (2007). Gaps in the family networks of older people in three Indonesian communities. Journal of Cross-Cultural Gerontology, 22(1), 1-25. doi: $10.1007 / \mathrm{s} 10823-006-9013-3$

Schwede, L. (1991). Family Strategies of Labor Allocation and Decision-making in a Matrilineal, Islamic Society: The Minangkabau of West Sumatra, Indonesia. (Degree of Doctor of Philosophy), Cornell University, New York.

Sen, A. (1985a). Commodities and capabilities. Amsterdam: North-Holland.

Sen, A. (1985b). Well-Being, Agency and Freedom: The Dewey Lectures 1984. The Journal of Philosophy, 82(4), 169-221.

Sen, A. (1989). Cooperation, Inequality, and the Family. Population and Development Review, 15, 6176.

Sen, A. (1990). Gender and Cooperative Conflicts. In I. Tinker (Ed.), Persistent Inequalities Women and World Development (pp. 123-149). Oxford: Oxford University Press.

Sen, A. (1993). Capability and Well-being. In M. C. Nussbaum \& A. Sen (Eds.), The quality of life (pp. xi, 453 p.). Oxford: Clarendon Press.

Sen, A. (2001). Development as freedom. Oxford ; New York: Oxford University Press.

Sen, A. (2009). The idea of justice. London: Allen Lane.

Sen, K. (1998). Indonesian Women at Work: Reframing the Subject. In K. Sen \& M. Stivens (Eds.), Gender and Power in Affluent Asia (pp. 323p.). London ; New York: Routledge.

Skinner, E. A. (1995). Perceived Control, Motivation and Coping. Thousand Oaks: Sage Publications. 
Statistics Indonesia, B. P. S. B., \& Macro International. (2008). Indonesia Demographic and Health Survey 2007 (pp. 545). Calverton, Maryland USA: BPS and Macro International.

Strauss, J., Witoelar, F., Sikoki, B., \& Wattie, A. M. (2009). The Fourth Wave of the Indonesia Family Life Survey (IFLS4): Overview and Field Report Rand Labor and Population working paper series: RAND Corporation.

Stutzer, A., \& Frey, B. S. (2010). Recent Advances in the Economics of Individual Subjective WellBeing. SSRN eLibrary.

Suryakusuma, J. I. (1996). The State and Sexuality in New Order Indonesia. In L. J. Sears (Ed.), Fantasizing the feminine in Indonesia (pp. xvi, 349 p). Durham: Duke University.

Tella, R. D., MacCulloch, R. J., \& Oswald, A. J. (2003). The Macroeconomics of Happiness. The Review of Economics and Statistics, 85(4), 809-827.

Thapan, M. (2003). Marriage, Well-Being, and Agency among Women. Gender and Development, 11(2), 77-84.

Tichenor, V. J. (1999). Status and Income as Gendered Resources: The Case of Marital Power. Journal of Marriage and Family, 61(3), 638-650.

Tiwon, S. (1996). Models and Maniacs Articulating the Female in Indonesia. In L. J. Sears (Ed.), Fantasizing the feminine in Indonesia (pp. xvi, 349 p). Durham: Duke University.

Vogler, C., Lyonette, C., \& Wiggins, R. D. (2008). Money, power and spending decisions in intimate relationships. The Sociological Review, 56(1), 117-143. doi: 10.1111/j.1467954X.2008.00779.x 
Weix, G. G. (2000). Hidden Managers at Home: Elite Javanese Women Running New Order Family. In J. Koning, M. Nolten, J. Rodenburg \& R. Saptari (Eds.), Women and households in Indonesia : cultural notions and social practices (pp. 299-314). Richmond, Surrey: Curzon.

Wolf, D. (2000). Beyond Women and the Household in Java Re-examining the Boundaries. In J. Koning, M. Nolten, J. Rodenburg \& R. Saptari (Eds.), Women and households in Indonesia : cultural notions and social practices (pp. 85-100). Richmond, Surrey: Curzon.

Yulindrasari, H., \& McGregor, K. (2011). Contemporary Discourses of Motherhood and Fatherhood in Ayahbunda, a Middle-Class Indonesian Parenting Magazine. Marriage \& Family Review, 47(8), 605-624. doi: 10.1080/01494929.2011.619304

1 While it is important not to depict women as perpetual victims (Cornwall, Harrison, \& Whitehead, 2007), it is also necessary to acknowledge that, as a group, women almost never have greater agency than men (as a group). This is a result of the particular patriarchal bargain within their (Kandiyoti, 1988) although there is evidence that doing gender (a person's behaviour is affected by the opinions and expectations of other people or by social influences) constrains the behaviour of both men and women as individuals (Bertrand, Kamenica, \& Pan, 2013; Bittman, England, Folbre, Sayer, \& Matheson, 2003; Greenstein, 1995, 2000; Gupta, 2006; Ono \& Raymo, 2006; Tichenor, 1999). The patriarchal bargain is not uniform and women can have different levels of agency within their households and societies based on seniority, piety, social class or caste or other social groupings such as ethnicity or sexual orientation. While men can also be constrained by social norms which interact with their ethnicity, sexual orientation or class (Black, 1994; Kandiyoti, 1994), women experience discrimination on an extra dimension compared to men - that of gender.

2 These additional laws differ between male and female civil servants, compounding the disadvantage female civil servants already face with regards to job security and career progression (Suryakusuma, 1996). 
3 These were the head of household and spouse, two of the household head's children aged up to 14 years old who were randomly selected, someone over 50 years old and someone aged between 15 and 49 and his or her spouse from the remaining household members for $25 \%$ of the households sampled (Strauss et al., 2009)

4There is a great deal of heterogeneity in household domestic arrangements in practice, despite the centrality of the idea of the nuclear family in government propaganda and policy (Nolten, 2000; Saptari, 2000). Research has indicated that even when families (related or otherwise) co-reside in one household, certain types of household decisions are typically made by each family unit independently of the other family units with variations between ethnic groups (Benda-Beckmann \& Benda-Beckmann, 2000; Jufri \& Watson, 1998; Koning, 2000; Sanday, 2002; Schwede, 1991). As we are primarily interested in studying the relationship between well-being and agency among spouses, we focus mainly on decision-making by respondents and their spouses, rather than the extended family.

$5 \mathrm{~A}$ version of the ordered probit model pooled across genders was considered as pooled models maximize efficiency through greater sample sizes. However, the ethnographic and anthropological literature on Indonesia indicates that a fully pooled model is inappropriate for this dataset. It is common in the subjective well-being literature for models to be estimated separately for men and women as there would be systematic differences and differences in the error term between genders.

6 While detailed community level data was collected for IFLS enumeration areas, for households which had moved to non-IFLS areas, a much lighter version of community level data was collected. As such, we include community access to mid-wives and electricity as our community characteristics as this data was collected for both IFLS and non-IFLS enumeration areas. 
7 The proportion of people who attended junior high school and beyond was much lower at $41 \%$ (Statistics Indonesia \& Macro International, 2008).

8 Analysis of the decision-making data collected from both men and women indicates that the responses given by both spouses with regards to decision-making roles and responsibilities is fairly consistent across all the different types of decisions which mitigates concerns of inconsistencies in the responses provided by the men and women in the sample (Frankenberg \& Thomas, 2001).

9 These are decisions made either wholly or jointly by parties other than the respondent and his or her spouse. The involvement of third parties in household decision-making depends on the type of decision in question. Overall, less than $10 \%$ of decisions were made by third parties, specifically, less than $1 \%$ of cash-giving or gift decisions, less than $2 \%$ of savings-related decisions, less than $5 \%$ of large household expenditure decisions and less than $10 \%$ of child-related or routine household expenditure decisions.

10 We are grateful to one of our referees for bringing this interpretation of the results to our attention.

11 The marginal effects associated with the estimation of Model 2 are evaluated at the mean. This reflects how making a particular type of household decision affects the likelihood of a person being in a category on the well-being scale above or below the mean of well-being. We have estimated marginal effects for Model 2 which was our largest sample. Marginal effects for the other models are available on request. 